\title{
Fine Structure of the Spore Sheath in Streptoverticillium Species
}

\author{
By T. CROSS AND R. W. ATTWELL \\ Postgraduate School of Studies in Biological Sciences, \\ University of Bradford, BD7 I DP, Yorkshire \\ AND R. LOCCI \\ Istituto di Patologia Vegetale, Universita di Milano, 20I33, Milan, Italy
}

(Received Io November 1972)

Actinomycetes bearing whorls and umbels of short spore chains at regular intervals on their long aerial hyphae and originally included in the genus Streptomyces were later reclassified as a separate genus Streptoverticillium (Baldacci, I958, Baldacci, Farina \& Locci, I 966). However, these two genera share a number of common morphological, developmental and physiological characteristics which have prevented several workers from accepting their separate generic status (e.g. Krasilnikov, I970). The similarities have also appeared to discourage the further study of streptoverticillia and it has been assumed that other properties are shared.

During an extensive scanning electron microscope study of the morphology of Streptoverticillium species (Locci \& Petrolini Baldan, I 97I) it was noticed that all showed twisted umbel hyphae which later became subdivided into the chains of arthrospores. No true spirals were observed and when viewed in silhouette by means of the transmission electron, microscope the individual spores have appeared smooth (Shirling \& Gottlieb, I968 $a, b$, 1969) and lack the conspicuous warts, spines and hairs (Küster, 1955) or knobs (Lyons \& Pridham, 197I) which ornament certain Streptomyces species. These surface structures develop from the spore sheath (Arai \& Kuroda, 1962; Rancourt \& Lechevalier, 1964) which also characteristically bears many short and randomly arranged elements termed fibres or rodlets (Vernon, I955; Hopwood \& Glauert, I96I; Dietz \& Mathews, I962; Wildermuth, 1970, 1972 $a, b$; Enquist \& Bradley, I97I; Wildermuth, Wehrli \& Horne, I97I ; Williams, Bradshaw, Costerton \& Forge, 1972). The fine structure of the Streptoverticillium spore sheath was examined to explain the twisted form of the umbel hyphae and the lack of appendages.

\section{METHODS}

Early studies concentrated on Streptoverticillium griseoverticillatus ISP 5507 but were later extended to include many of the species described by Locci, Baldacci \& Petrolini Baldan (1969). The sporulating aerial hyphae grown on inclined coverslips embedded in Czapek's agar were coated with gold palladium under vacuum (Locci \& Petrolini Baldan, I97I) and examined with a Stereoscan electron microscope (Mark 2A, Cambridge Instrument Company, Cambridge). Spores were also viewed in silhouette using an AEI EM6B transmission electron microscope and the methods recommended for the International Streptomyces Project (Shirling \& Gottlieb, 1966). 

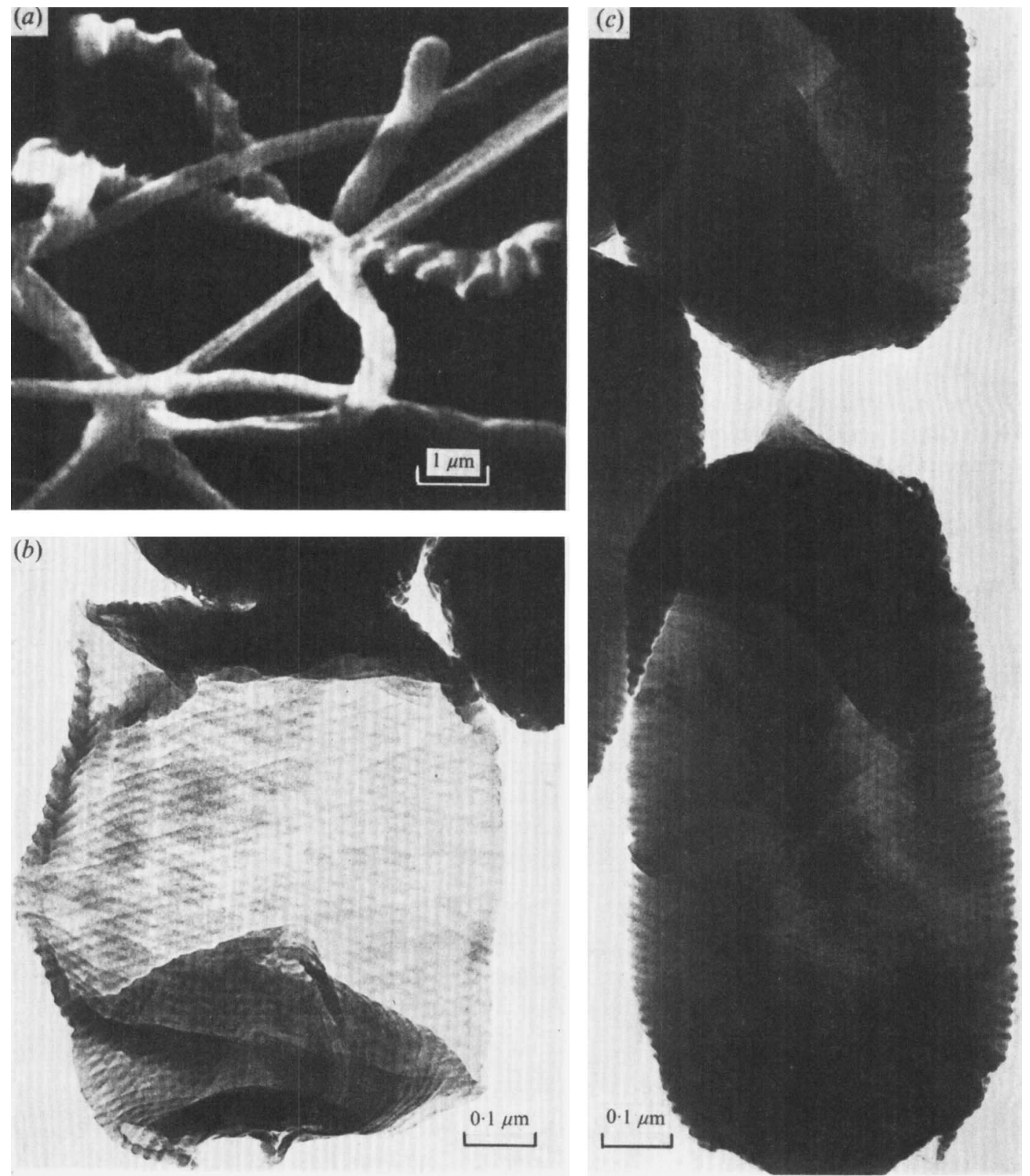

Fig. I. Streptoverticillium griseoverticillatus. (a) Scanning electron micrograph showing twisted umbel hyphae. (b) Transmission electron micrograph showing a detached portion of the spore sheath. (c) Transmission electron micrograph of spores enclosed within sheath.

\section{RESULTS AND DISCUSSION}

The aerial hyphae of Streptoverticillium griseoverticillatus showed the characteristic twisted form of the umbel branches prior to the appearance of a beaded spore-chain outline (Fig. I $a$ ). The chain of spores was surrounded by a thin sheath which contained a con- 
spicuous and continuous helical thickening (Fig. I $b$ ). Segments of the sheath still invested individual spores when the latter separated. Numerous parallel sheath fibres, in the form of a multiple helix, gave the illusion of basketwork when segments were viewed in transparency (Fig. I c) after the shrinkage of the enclosed spore. Individual fibres were about $10 \mathrm{~nm}$ in diameter and at least ro such fibres were involved in the helical pattern.

We have seen this regular helically thickened sheath in all representative species chosen from the I2 Streptoverticillium series described by Locci et al. (1969). Careful examination of Streptoverticillium spore electron micrographs in earlier papers confirm this to be a common feature of the genus (e.g. Streptoverticillium baldaccii in Farina \& Locci, 1966; S. mashuensis in Shirling \& Gottlieb, $1968 b$ ).

It is postulated that the amorphous material of the sheath or the fibrous thickening contracts during spore maturation or during preparation for scanning electron microscopy, so imparting the twisted form to the sporulating hyphae. The characteristic appearance of the Streptoverticillium sheath, which is quite unlike that described for the several Streptomyces species already examined, supports the separation of these organisms into distinct genera. The absence of short rodlets from the sheath may also explain the absence of conspicuous surface appendages for it has been suggested that these subunits appear to aggregate to form the spines and hair-like projections (Wildermuth, 1972a; Williams et al. 1972).

This investigation was supported by grants from the Science Research Council and Unilever Limited.

\section{REFERENCES}

Arai, T. \& Kuroda, S. (I962). Fine structure of the spiny spores of Streptomyces. Journal of Bacteriology $\mathbf{8 3}$, 924-925.

BaLDACCI, E. (1958). Development in the classification of Actinomycetes. Giornale di Microbiologia 6, $10-27$.

Baldacci, E., Farina, G. \& LocCI, R. (1966). Emmendation of the genus Streptoverticillium Baldacci (I958) and revision of some species. Giornale di Microbiologia 14, I53-I 7I.

Dietz, A. \& MAthews, J. (I962). Taxonomy by carbon replication. I. An examination of Streptomyces hygroscopicus. Applied Microbiology 10, 258-263.

EnQuist, L. W. \& BRAdley, S. G. (I97I). Characterization of deoxyribonucleic acid from Streptomyces venezuelae spores. Developments in Industrial Microbiology 12, 225-236.

FARINA, G. \& Locci, R. (1966). Contributo allo studio di Streptoverticillium: descrizione di una nuova specie (Streptoverticillium baldaccii sp. nov.) ed esame di alcune species precedentemente delinate. Giornale di Microbiologia 14, 33-52.

Hopwood, D. A. \& Glauert, A. M. (1961). Electron microscope observations on the surface structures of Streptomyces violaceoruber. Journal of General Microbiology 26, 325-330.

Küster, E. (1955). Beitrag zur Genese und Morphologie der Streptomycetensporen. Zentralblatt fiir Bakteriologie, Parasitenkunde, Infektionskrankheiten und Hygiene (Abteilung II) ro8, 376-382.

Krasilnikov, N. A. (1970). The Actinomycetes (Higher Forms). Moscow: Nauka.

Locci, R., Baldacci, E. \& Petrolini Baldan, B. (1969). The genus Streptoverticillium, a taxonomic study. Giornale di Microbiologia 17, I-60.

Locci, R. \& Petrolini Baldan, B. (197I). On the spore formation process in Actinomycetes I. Morphology and development of Streptoverticillium species as examined by scanning electron microscopy. Rivista di Patologia Vegetale, Serie IV 7 (Supplement), 3-19.

Lyons, A. J. \& Pridham, T. G. (197I). Streptomyces torulosus sp.n., an unusual knobbly-spored taxon. Applied Microbiology 22, 190-193.

Rancourt, M. W. \& Lechevalier, H. A. (1964). Electron microscopic study of the formation of spiny conidia in species of Streptomyces. Canadian Journal of Microbiology 1o, 3 I I-316.

Shirling, E. B. \& GotTlieb, D. (I966). Methods for characterization of Streptomyces species. International Journal of Systematic Bacteriology r6, 313-340.

Shirling, E. B. \& Gottlieb, D. (1968a). Co-operative description of type cultures of Streptomyces II. Species descriptions from first study. International Journal of Systematic Bacteriology 18, 69-189. 
ShiRling, E. B. \& Gottlieb, D. (I968 b). Co-operative description of type cultures of Streptomyces III. Additional species descriptions from first and second studies. International Journal of Systematic Bacteriology 18, 279-393.

Shirling, E. B. \& GotTlieb, D. (1969). Co-operative description of type cultures of Streptomyces IV. Species descriptions from the second, third and fourth studies. International Journal of Systematic Bacteriology 19, 392-512.

VERNON, T. R. (1955). Spore formation in the genus Streptomyces. Nature, London 176, 935-936.

WILDERMUTH, H. (I970). Surface structure of streptomycete spores as revealed by negative staining and freeze etching. Journal of Bacteriology Ior, 318-322.

WildERMUTH, H. (1972a). The surface structure of spores and aerial hyphae in Streptomyces viridochromogenes. Archiv für Mikrobiologie 81, 309-320.

WiLDERMUTH, H. (1972 b). Morphological surface characteristics of Streptomyces glaucescens and $S$. actimycini, two streptomycetes with 'hairy' spores. Archiv für Mikrobiologie 81, 321-332.

Wildermuth, H., WehrLI, E. \& HoRNe, R. W. (I97I). The surface structure of spores and aerial mycelium in Streptomyces coelicolor. Journal of Ultrastructure Research 35, I68-I80.

Williams, S. T., Bradshaw, R. M., Costerton, J. W. \& Forge, A. (I972). Fine structure of the spore sheath of some Streptomyces species. Journal of General Microbiology 72, 249-258. 